\title{
IMPACT OF FALLOW ON SOIL HEALTH IN MOKOKCHUNG DISTRICT, NAGALAND, INDIA
}

\author{
Wati TEMJEN*, Maibam Romeo SINGH, Tali JUNGLA \\ Centre for Biodiversity, Department of Botany, Nagaland University, 798627 Lumami, India
}

Received 30 October 2020; accepted 07 April 2021

\footnotetext{
Highlights

$>$ Study was conducted by selecting two sites i.e. Shifting Cultivation Site (SCS) and Forest Regeneration Site (FRS) at Mokokchung district, Nagaland, India.

Soil $\mathrm{pH}$, moisture, temperature, SOC, available nitrogen and fungal population were recorded.

FRS site was found to have a greater soil quality as compared to the SCS.

$>$ Study displays the detrimental effect of the Shifting Cultivation on the quality of soil.

Highlights the need for monitoring and rectification at source to preserve the quality of the soil.
}

\begin{abstract}
Two sites were selected from the district of Mokokchung, Nagaland viz., Forest Regeneration Site (FRS) and Shifting Cultivation Site (SCS). At FRS, soil pH ranged from 5.00 $\pm 0.13-5.50 \pm 0.04$, soil moisture 35.44 $\pm 1.09-53.39 \pm 0.84 \%$, soil temperature $14.33 \pm 0.47-23.83 \pm 0.23{ }^{\circ} \mathrm{C}$, soil organic carbon $2.20 \pm 0.08-3.03 \pm 0.02 \%$ and available nitrogen $424.48 \pm 6.73-$ $547.46 \pm 2.10 \mathrm{Kg} / \mathrm{ha}$. At SCS, soil pH ranged from $5.94 \pm 0.24-6.53 \pm 0.02$, soil moisture $30.32 \pm 2.64-45.72 \pm 0.98 \%$, soil temperature $17.83 \pm 0.62-26.1 \pm 0.08{ }^{\circ} \mathrm{C}$, soil organic carbon $1.67 \pm 0.29-2.34 \pm 0.08 \%$ and available nitrogen $324.16 \pm 8.42-$ $443.20 \pm 1.06 \mathrm{Kg} / \mathrm{ha}$. Significant correlation between soil temperature, $\mathrm{pH}$, soil moisture and available nitrogen was observed at FRS, while correlation of soil moisture and $\mathrm{pH}$ was observed at SCS. A total of 21 fungal species belonging to 13 genera were identified from the two sites. FRS had more fungal diversity than SCS. The genus Aspergillus was dominant in both the studied sites. The study observed the detrimental effect of the shifting cultivation on soil health and highlights the need for monitoring and rectification to preserve soil health.
\end{abstract}

Keywords: land use, soil quality, shifting cultivation, Jhum fallow, landscape management, Nagaland.

\section{Introduction}

Shifting cultivation has its origins in the Mediterranean agriculture system (Karlen et al., 1994) and is one of the major forms of cropping system practised in north-east India. Shifting cultivation consists of three phases, namely, clearing a forest area by slashing vegetation and burning, cultivation of crops for a year or more and a variable fallow period (Mertz et al., 2009; Zodinpuii et al., 2016). Locally, this practise is called jhuming and the cultivators are known as the jhumias (Devi \& Choudhury, 2013). However, with the increase in agricultural activity, there is a dramatic decrease in the fallow period. This reduced fallow cycle has been reported as a threat to biodiversity and soil conservation practises (Duguma et al., 2001; Van et al., 2008). Reports on the negative impact of shifting cultivation consists of lowering of soil fertility, increased erosion, reduced crop yield and watershed siltation (Mertz, 2002; Maithani, 2005; Ziegler et al., 2009). Further, fallow frequency, tillage, and chemical weed control also affects soil quality (Nielsen \& Calderón, 2011). Unsustainable farming practises lead to irreversible damage to the ecosystem, as such implementation of optimum fallow cycle is vital to improve soil health (Devi \& Choudhury, 2013). Several workers have also suggested that forest restoration can improve the concentrations of carbon and nitrogen in the soil by accumulative organic matter input from aboveground litterfall and root turnover (Chang et al., 2011; Deng et al., 2013; Hume et al., 2016). Hence, this capacity of the soil to function in the current and the future reflects its quality (Doran \& Parkin, 1994) and effort should be implemented on soil quality improvement and

*Corresponding author. E-mail: temjen.wati29@gmail.com

Copyright $\odot 2021$ The Author(s). Published by Vilnius Gediminas Technical University

This is an Open Access article distributed under the terms of the Creative Commons Attribution License (http://creativecommons.org/licenses/by/4.0/), which permits unrestricted use, distribution, and reproduction in any medium, provided the original author and source are credited. 
its conservation for its sustainable utilisation under varied uses and management (Unger et al., 1991).

Soil factors such as soil $\mathrm{pH}$, moisture, temperature, organic carbon and nitrogen influence the distribution of fungi (Kumar et al., 2015). The role of soil fungi is vital in the soil for nutrient cycling, disease suppression and water dynamics, which ultimately creates plants that become healthier and more vigorous (Jenkins, 2005). There are reports of lowered microbial population in shifting cultivation land as compared to forest lands (Gupta et al., 1986). This practise of shifting cultivation has been carried out since times immemorial in the state of Nagaland, a state in the north-east corner of India bordering Myanmar. The study aims to work out on some selected soil physico-chemical parameters and also to estimate the difference in fungal population from two selected sites located in the district of Mokokchung, Nagaland viz., Forest Regeneration Site (FRS) with a fallow period of 10 years and a Shifting Cultivation Site (SCS), which after undergoing its fallow period of 10 years, is currently in its $3^{\text {rd }}$ year of crop cultivation.

\section{Materials and methods}

Site selection: Two sites were selected in Longsa village under Mokokchung District, Nagaland. The first site is a Forest Regeneration Site (FRS) located at Latitude $26^{\circ} 14^{\prime} 31^{\prime \prime} \mathrm{N}$ and Longitude $94^{\circ} 31^{\prime} 44^{\prime}{ }^{\prime} \mathrm{E}$ with an altitude of $813 \mathrm{~m}$ above msl. This site was a site of shifting cultivation (2008-2011) before being converted into a fallow land. Site FRS remained undisturbed for a period of 10 years (2011-2020). The villagers have reported that no agricultural activity has been carried out during the fallow period. Plants like Ageratum conyzoides, Albizzia chinensis, Amaranthus sp., Angiopteris sp., Artemisia vulagris, Azadirachta indica, Bambusa pallida, Eupatorium adenophorum, Macaranga denticulate, Pueraria, Mikania cordata, Schima wallichi, Sonchus wightianus, Thysanolaena maxi$m a$ and Terminalia myriocarpa are dominant at FRS. The second site is a Shifting Cultivation Site (SCS) with a geographical coordinate of Latitude $26^{\circ} 13^{\prime} 38^{\prime \prime} \mathrm{N}$ and Longitude $94^{\circ} 32^{\prime} 24^{\prime \prime} \mathrm{E}$ with an altitude of $1024 \mathrm{~m}$ above msl. This site was kept abandoned for 10 years (2007-2017) with no agricultural activities after which cultivation has been carried out continuously at SCS for the last 3 consecutive years (2017-2020). Crops like Manihot esculenta, Oryza sativa, and Zea mays are cultivated at this site. FRS and SCS are separated by a distance of $1.9 \mathrm{~km}$.

Physico-chemical parameters of soil sample: Preliminary site selection started from January 2019-February 2019. Seasonally, soil samples were collected randomly from both sites during March 2019 to February 2020. Further, samples were collected from both the sites on the same day owing to the short distance between the two sites. Samples were collected for spring (March-May 2019), summer (June-August 2019), autumn (SeptemberNovember 2019) and winter (Decemeber 2019-February 2020). Samples were collected from 0-15 cm layer depth.
Soil samples were combined to form a composite sample. For soil $\mathrm{pH}, 5 \mathrm{~g}$ of soil were mixed with distilled water at a ratio 1:2.5 $\mathrm{ml}$ and kept in rotary shaker for 15 minutes. The suspension was then allowed to settle for 5 minutes and $\mathrm{pH}$ was measured using digital systronic $\mathrm{pH}$ meter 361 . Soil moisture was measured by Gravimetric method. For soil nutrients and physio-chemical analysis, air-dried samples were sieved to pass through $<2 \mathrm{~mm}$ screen. Soil temperatures were recorded during sampling with a soil thermometer. Soil organic carbon was determined following the wet digestion of (Walkley \& Black, 1934). Available Nitrogen was determined using KEL PLUS Nitrogen analyser. All the samples were analysed in triplicates and values are give in mean \pm S.D.

Isolation of fungi: Soil samples were collected from $0-15 \mathrm{~cm}$ layer depth from the two sites. Fungal species were isolated in Potato Dextrose Agar (Himedia) plates supplemented with streptomycin sulphate. For soil dilution (Waksman, 1921), $1 \mathrm{gm}$ of soil sample was diluted in $10 \mathrm{ml}$ of sterilized distilled water to make microbial suspension $10^{-1}$ to $10^{-5}$. Dilution of $10^{-2}$ to $10^{-5}$ were used to isolate fungi. One $\mathrm{ml}$ of dilution was taken from each serial dilution sample in triplicate form and transferred to plates of Potato Dextrose Agar (PDA). PDA medias were supplemented with $0.03 \mathrm{~g} / \mathrm{L}$ streptomycin sulphate for inhibiting any bacterial growth and allowed to solidify. Plates were incubated at $25 \pm 1{ }^{\circ} \mathrm{C}$ for $5-7$ days in dark. Colonies were inoculated in PDA plates and incubated at $25 \pm 1{ }^{\circ} \mathrm{C}$ for $5-7$ days. Microscopical examination consisted of preparing temporary lacto-phenol cotton blue slides and observation under compound microscope. The fungi were identified with the help of literatures (Gillman, 1957; Nagmani et al., 2006; Webster \& Weber, 2007).

Statistical analysis: SPSS version 16.0 was used for the calculation of Pearson's correlation. The data obtained were also subjected to analysis of variance (ANOVA) and the means were compared with Duncan's multiple range test to determine the effect of seasons on soil parameters (DMRT).

\section{Results and discussion}

\subsection{Soil physico-chemical parameters at FRS and SCS}

Table 1 shows the physico-chemical parameters of soil at FRS. Soil $\mathrm{pH}$ value ranged from minimum $5.00 \pm 0.13$ during winter and maximum $5.50 \pm 0.04$ during autumn. The lowest value of soil moisture content of $35.44 \pm 1.09 \%$ was recorded during winter while the highest of $53.39 \pm 0.84 \%$ was recorded during autumn. Soil temperature, varied from $14.33 \pm 0.47-23.83 \pm 0.23{ }^{\circ} \mathrm{C}$. The lowest temperature was recorded during winter while highest temperature was recorded during autumn. Highest SOC was reported during summer $(3.03 \pm 0.02 \%)$ while lowest value of $2.20 \pm 0.08 \%$ was reported during winter. Lower value of available nitrogen $424.48 \pm 6.73 \mathrm{Kg} / \mathrm{ha}$ was recorded during winter, while highest value of $547.46 \pm 2.10 \mathrm{Kg} / \mathrm{ha}$ was 
observed during autumn. Table 2 display the physicochemical parameters of soil at SCS. Autumn displayed the highest $\mathrm{pH}$ value $(6.53 \pm 0.02)$, while winter season had the lowest $\mathrm{pH}$ value $(5.94 \pm 0.24)$. Lowest soil moisture content of $30.32 \pm 2.64 \%$ was observed during winter, while highest value of $45.72 \pm 0.98 \%$ was observed during autumn. Soil temperature was minimum during winter $\left(17.83 \pm 0.62^{\circ} \mathrm{C}\right)$ while maximum value was observed during summer $\left(26.1 \pm 0.08^{\circ} \mathrm{C}\right)$. The lowest value of SOC was observed during winter $(1.67 \pm 0.029 \%)$ while maximum value of $2.34 \pm 0.08 \%$ was observed during summer. The highest value of available nitrogen was observed during summer with a value of $443.20 \pm 1.06 \mathrm{Kg} / \mathrm{ha}$, while lowest value of $324.16 \pm 8.4 \mathrm{Kg} / \mathrm{ha}$ was reported during winter.

The soil samples were found to be moderately acidic in both sites. The $\mathrm{pH}$ range of most productive agricultural soils is between 5.5 and 7.5 (Wubie, 2013). $\mathrm{pH}$ was found to be lower at FRS compared to SCS in all the seasons (Figure 1). One factor for the increased $\mathrm{pH}$ at SCS might be the practise of burning of soils, which supplies ashes to the soil and subsequently raised $\mathrm{pH}$ at SCS (Devi \& Choudhury, 2013). A positive correlation of $\mathrm{pH}$ was observed with soil moisture in both the sites (Table 3 and Table 4). This correlation may be attributed to the reports of soil water content increasing the soil $\mathrm{pH}$, making it more alkaline (Smyth, 2012). Soil moisture has a profound effect on soil microbial activity (Liu et al., 2009). FRS had higher soil moisture than SCS (Figure 2). Several workers have reported that soil moisture increased in agricultural systems that employ fallow (Jones \& Popham, 1997; Nielsen et al., 2002). The presence of higher soil moisture at FRS may be attributed to higher water retention and surface water entry in the soil due to the presence of denser vegetation (Devi \& Choudhury, 2013). Among soil properties,

Table 1. Seasonal variation in physico-chemical characteristics of soil at FRS

\begin{tabular}{|l|c|c|c|c|c|}
\hline Seasons & $\mathrm{pH}$ & $\begin{array}{c}\text { Soil moisture } \\
(\%)\end{array}$ & $\begin{array}{c}\text { Soil temperature } \\
\left({ }^{\circ} \mathrm{C}\right)\end{array}$ & $\begin{array}{c}\text { Soil organic } \\
\text { carbon }(\%)\end{array}$ & $\begin{array}{c}\text { Available nitrogen } \\
(\mathrm{Kg} / \mathrm{ha})\end{array}$ \\
\hline Spring & $5.31 \pm 0.94$ & $42.97 \pm 0.66$ & $21.83 \pm 0.23$ & $2.33 \pm 0.04$ & $523.88 \pm 1.36$ \\
\hline Summer & $5.46 \pm 0.23$ & $50.96 \pm 0.61$ & $23.66 \pm 0.47$ & $3.03 \pm 0.02$ & $511.39 \pm 0.87$ \\
\hline Autumn & $5.50 \pm 0.04$ & $53.39 \pm 0.84$ & $23.83 \pm 0.23$ & $2.87 \pm 0.04$ & $547.46 \pm 2.10$ \\
\hline Winter & $5.00 \pm 0.13$ & $35.44 \pm 1.09$ & $14.33 \pm 0.47$ & $2.20 \pm 0.08$ & $424.48 \pm 6.73$ \\
\hline
\end{tabular}

Table 2. Seasonal variation in physico-chemical characteristics of soil at SCS

\begin{tabular}{|l|c|c|c|c|c|}
\hline Seasons & $\mathrm{pH}$ & $\begin{array}{c}\text { Soil moisture } \\
(\%)\end{array}$ & $\begin{array}{c}\text { Soil temperature } \\
\left({ }^{\circ} \mathrm{C}\right)\end{array}$ & $\begin{array}{c}\text { Soil organic } \\
\text { carbon }(\%)\end{array}$ & $\begin{array}{c}\text { Available nitrogen } \\
(\mathrm{Kg} / \mathrm{ha})\end{array}$ \\
\hline Spring & $6.30 \pm 0.09$ & $39.01 \pm 1.10$ & $24.83 \pm 0.23$ & $1.95 \pm 0.04$ & $417.64 \pm 0.81$ \\
\hline Summer & $6.41 \pm 0.08$ & $40.13 \pm 0.89$ & $26.1 \pm 0.08$ & $2.34 \pm 0.08$ & $443.20 \pm 1.06$ \\
\hline Autumn & $6.53 \pm 0.02$ & $45.72 \pm 0.98$ & $25.16 \pm 0.23$ & $1.98 \pm 0.18$ & $381.22 \pm 0.80$ \\
\hline Winter & $5.94 \pm 0.24$ & $30.32 \pm 2.64$ & $17.83 \pm 0.62$ & $1.67 \pm 0.29$ & $324.16 \pm 8.42$ \\
\hline
\end{tabular}

Table 3. Correlation matrix among the soil parameters at FRS

\begin{tabular}{|l|c|c|c|c|c|}
\hline & $\mathrm{pH}$ & Soil moisture & Soil temperature & Soil organic carbon & Available nitrogen \\
\hline $\mathrm{pH}$ & 1 & & & & \\
\hline Soil moisture & $.978^{*}$ & 1 & & & \\
\hline Soil temperature & $.986^{*}$ & .930 & .801 & 1 & \\
\hline Soil organic carbon & .870 & .928 & $.955^{*}$ & .636 & 1 \\
\hline Available nitrogen & .933 & .864 & & \\
\hline
\end{tabular}

Note: ${ }^{\star}$ Correlation is significant at the 0.05 level (2-tailed).

Table 4. Correlation matrix among the soil parameters at SCS

\begin{tabular}{|l|c|c|c|c|c|}
\hline & $\mathrm{pH}$ & Soil moisture & Soil temperature & Soil organic carbon & Available nitrogen \\
\hline $\mathrm{pH}$ & 1 & & & & \\
\hline Soil moisture & $.985^{*}$ & 1 & & & \\
\hline Soil temperature & .932 & .871 & .846 & 1 & \\
\hline Soil organic carbon & .721 & .591 & .906 & .909 & \\
\hline Available nitrogen & .699 & .582 & & \\
\hline
\end{tabular}

Note: ${ }^{\star}$ Correlation is significant at the 0.05 level (2-tailed). 
temperature is considered as the most important factor when it comes to mineralization process of organic matter (Arevalo et al., 2012). Temperature was found to be moderately higher at SCS compared to FRS. Although temperature decreases with altitude, an increase in temperature was observed during the study (Figure 3). This may be attributed to the direct exposure of the surface soil to sunlight in absence of dense vegetation at SCS. A positive correlation of temperature with $\mathrm{pH}$ and available nitrogen was found at FRS (Table 3). This correlation may be attributed to increased soil temperature stimulating microbial activity, thereby increasing the availability of plant nutrients in the soil (Onwuka \& Mang, 2018). As a result, higher nitrogen levels were recorded during the warmer seasons. $\mathrm{pH}$ value meanwhile decreased during the colder season and increased during warmer season. This may be attributed to hydrogen ions being diluted by water during the rainy season (Lalmuansangi et al., 2019). SOC was higher at FRS than SCS in all the seasons during the study period (Figure 4). Similar reports of increased organic carbon in forest soils as compared to agricultural land was reported by Dadhwal et al. (2011) and Singh and Munth (2013). SOC has been reported to be a key control with regards to soil fertility and agricultural (Tiessen et al., 1994). The increased SOC in FRS may be attributed to the lack of disturbance to the natural vegetation, leading to higher litterfall. Another factor effecting SOC may be the difference in altitude between the two studied sites. Altitude may affect the plant species richness which in turn effects the plant community. Shiek et al. (2009) reported on lower input of organic carbon in the soil of higher altitude due to decreased vegetation. Lowered SOC in SCS may also be due to continues tillage and subsequent runoff from the land (Tasung \& Ahmed, 2017). There is also a significant alarm that the practise of shifting cultivation could exhaust the soil carbon stock, which could lead to a rise of carbon dioxide percentage in the atmosphere (Bruce et al., 1999). No significant correlation was observed in both the sites. The values of available nitrogen showed a trend of increase in its concentrations at FRS as compared to SCS (Figure 5). Similar trends were reported by Xu et al. (2018). Temperature is the most important climatic factor controlling soil nitrogen. Increased temperature leads to an increase in soil available nutrients because of accelerated decomposition of soil organic matter. The positive correlation of available nitrogen with temperature at FRS was observed (Table 3 ). The increase in temperature may lead to an increase in nitrogen levels during the warmer season as compared to the colder season. No correlation was observed at SCS. Increased fallow periods have been reported to enhance the accumulation of nitrate through mineralization of organic matter (Campbell et al., 1990). Singh and Jamir (2017) also reported that continuous cropping removes enormous amounts of nutrients from the soil. It is observed that soil quality was better at FRS than SCS in all the seasons. The effect of seasons on soil parameters at FRS and SCS are also highlighted in Table 5 and Table 6. DMRT test revealed that changes in the soil

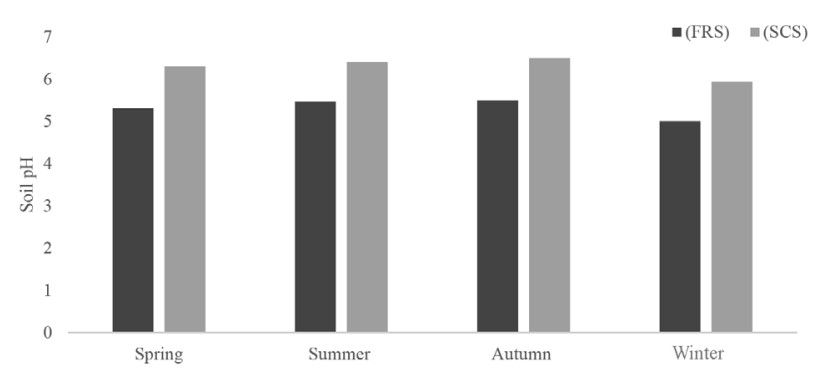

Figure 1. Seasonal variation in soil pH at FRS and SCS

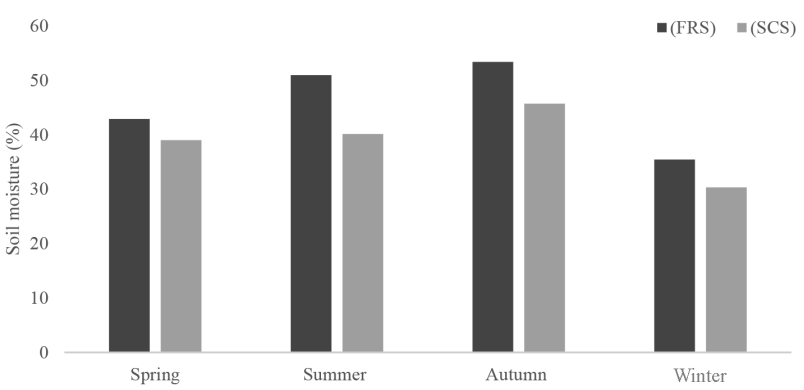

Figure 2. Seasonal variation in soil moisture at FRS and SCS

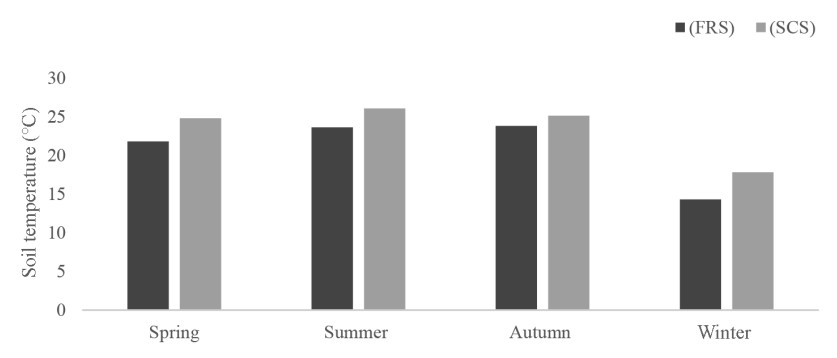

Figure 3. Seasonal variation in soil temperature at FRS and SCS

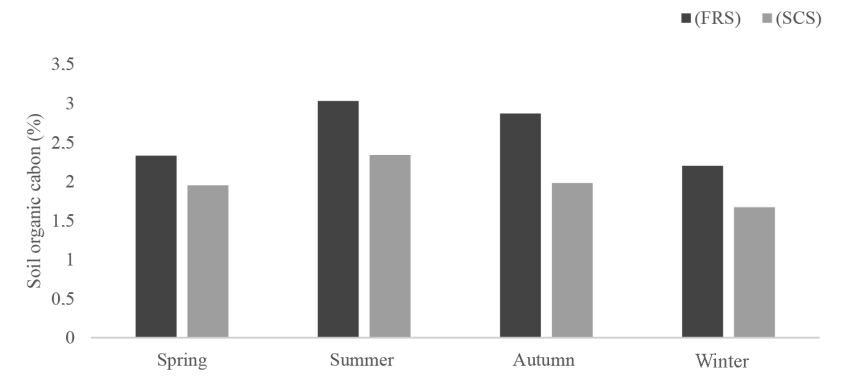

Figure 4. Seasonal variation in soil organic carbon at FRS and SCS

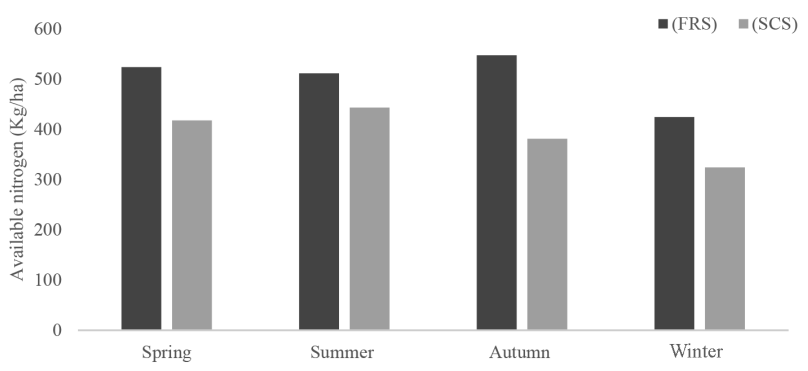

Figure 5. Seasonal variation in soil available nitrogen at FRS and SCS 
physico-chemical parameters were also affected seasonally. Mizra and Patil (2020) reported on the effect of season on physico-chemical properties of soil collected from Gautala reserve forest, Jalgaon, Maharashtra. Soil property is reliant on both biotic and abiotic components that vary spatially and seasonally (Dar et al., 2018). During the study, FRS and SCS had an altitudinal difference of $211 \mathrm{~m}$. With variation in altitude, climatic factor changes. Such changes correspond to change in soil biota impacting soil quantity and quality (Dar et al., 2012).

\subsection{Fungal population at FRS and SCS}

FRS had a total of 18 fungal populations belonging to 11 genera (Table 7). Maximum diversity was observed in summer followed by spring, autumn and winter respectively. It was observed that the genus Aspergillus was the dominant genus with 5 species at FRS, followed by Penicillium with 3 species. Whereas, at SCS, a total of 14 fungal populations belonging to 9 genera were recorded (Table 8). Maximum diversity was recorded during summer,

Table 5. Effect of season on soil parameters at FRS

\begin{tabular}{|l|c|c|c|c|c|}
\hline Seasons & Sarameters & Soil moisture $(\%)$ & $\begin{array}{c}\text { Soil temperature } \\
\left({ }^{\circ} \mathrm{C}\right)\end{array}$ & $\begin{array}{c}\text { Soil organic carbon } \\
(\%)\end{array}$ & $\begin{array}{c}\text { Available nitrogen } \\
(\mathrm{Kg} / \mathrm{ha})\end{array}$ \\
\hline Spring & $5.31^{\mathrm{b}}$ & $42.97^{\mathrm{b}}$ & $21.83^{\mathrm{b}}$ & $2.33^{\mathrm{b}}$ & $523.88^{\mathrm{c}}$ \\
\hline Summer & $5.46^{\mathrm{c}}$ & $50.96^{\mathrm{c}}$ & $23.66^{\mathrm{c}}$ & $3.03^{\mathrm{d}}$ & $511.39^{\mathrm{b}}$ \\
\hline Autumn & $5.50^{\mathrm{c}}$ & $53.39^{\mathrm{d}}$ & $23.83^{\mathrm{c}}$ & $2.87^{\mathrm{c}}$ & $547.47^{\mathrm{d}}$ \\
\hline Winter & $5.00^{\mathrm{a}}$ & $35.44^{\mathrm{a}}$ & $14.33^{\mathrm{a}}$ & $2.20^{\mathrm{a}}$ & $424.48^{\mathrm{a}}$ \\
\hline
\end{tabular}

Note: Values in the same column with different superscript are significantly different at $5 \%$ level by Duncan's multiple range test.

Table 6. Effect of season on soil parameters at SCS

\begin{tabular}{|l|c|c|c|c|c|}
\hline Seasons & Sarameters & Soil moisture $(\%)$ & $\begin{array}{c}\text { Soil temperature } \\
\left({ }^{\circ} \mathrm{C}\right)\end{array}$ & $\begin{array}{c}\text { Soil organic carbon } \\
(\%)\end{array}$ & $\begin{array}{c}\text { Available nitrogen } \\
(\mathrm{Kg} / \mathrm{ha})\end{array}$ \\
\hline Spring & $6.30^{\mathrm{b}}$ & $39.01^{\mathrm{b}}$ & $24.83^{\mathrm{b}}$ & $1.95^{\mathrm{b}}$ & $417.652^{\mathrm{c}}$ \\
\hline Summer & $6.41^{\mathrm{c}}$ & $40.13^{\mathrm{b}}$ & $26.10^{\mathrm{c}}$ & $2.34^{\mathrm{d}}$ & $443.21^{\mathrm{d}}$ \\
\hline Autumn & $6.53^{\mathrm{d}}$ & $45.72^{\mathrm{c}}$ & $25.16^{\mathrm{b}}$ & $1.98^{\mathrm{c}}$ & $381.22^{\mathrm{b}}$ \\
\hline Winter & $5.94^{\mathrm{a}}$ & $30.32^{\mathrm{a}}$ & $17.83^{\mathrm{a}}$ & $1.67^{\mathrm{a}}$ & $324.16^{\mathrm{a}}$ \\
\hline
\end{tabular}

Note: Values in the same column with different superscript are significantly different at $5 \%$ level by Duncan's multiple range test.

Table 7. Fungal diversity at FRS

\begin{tabular}{|c|c|c|c|c|}
\hline Fungal population & Spring & Summer & Autumn & Winter \\
\hline 1. Acremonium falciforme & + & + & + & - \\
\hline 2. Aspergillus candidus & + & + & + & - \\
\hline 3. Aspergillus flavus & + & + & + & + \\
\hline 4. Aspergillus fumigatus & + & + & - & + \\
\hline 5. Aspergillus niger & + & + & + & + \\
\hline 6. Aspergillus versicolor & - & + & - & - \\
\hline 7. Chaetomium sp. & + & + & - & - \\
\hline 8. Cladosporium chaldosporiodes & + & + & + & + \\
\hline 9. Geotrichum candidum & + & + & + & + \\
\hline 10. Humicola sp. & - & + & + & + \\
\hline 11. Mortierlla sp. & + & + & - & - \\
\hline 12. Mucor circinelloides & + & + & - & + \\
\hline 13. Paecilomyces carneus & - & + & + & - \\
\hline 14. Penecillium chrysogenum & + & + & + & + \\
\hline 15. Penecillium sp. 1 & + & + & - & - \\
\hline 16. Penecillium sp. 2 & - & - & + & - \\
\hline 17. Trichoderma harzianum & + & + & - & - \\
\hline 18. Trichoderma viride & + & + & - & - \\
\hline
\end{tabular}

Note: - indicate absent; + indicate present. 
Table 8. Fungal diversity at SCS

\begin{tabular}{|c|c|c|c|c|}
\hline Fungal population & Spring & Summer & Autumn & Winter \\
\hline 1. Aspergillus fumigatus & + & + & + & + \\
\hline 2. Aspergillus lentulus & - & + & - & - \\
\hline 3. Aspergillus niger & + & + & + & + \\
\hline 4. Aspergillus versicolor & + & + & - & - \\
\hline 5. Cladosporium chaldosporiodes & + & + & + & - \\
\hline 6. Humicola sp. & - & - & - & + \\
\hline 7. Mucor circinelloides & + & - & + & - \\
\hline 8. Paecilomyces carneus & + & + & - & + \\
\hline 9. Penicillium chrysogenum & + & + & + & - \\
\hline 10. Penicillium sp. 1 & + & + & + & + \\
\hline 11. Rhizopus sp. & + & + & - & - \\
\hline 12. Trichoderma harzianum & + & - & - & + \\
\hline 13. Trichoderma viride & - & + & + & + \\
\hline 14. Trychophyton sp. & - & + & + & - \\
\hline
\end{tabular}

Note: - indicate absent; + indicate present.

followed by spring, autumn and winter respectively. The genus Aspergillus was found to be dominant at SCS with 4 species, followed by the genus Penicillium and Trichoderma with two species each respectively. The total fungal population recorded from the two sites were Acremonium falciforme, Aspergillus candidus, Aspergillus flavus, Aspergillus fumigatus, Aspergillus lentulus, Aspergillus niger, Aspergillus versicolor, Chaetomium sp., Cladosporium chaldosporiodes, Geotrichum candidum, Humicola sp., Mortierlla sp., Mucor circinelloides, Paecilomyces carneus, Penicillium chrysogenum, Penicillium sp. 1, Penicillum sp. 2, Rhizopus sp., Trichoderma harzianum, Trichoderma viride and Trychophyton sp. FRS had more fungal population than SCS. Similar results were observed by Miah et al. (2010) who reported lowered fungal population in shifting cultivation sites as compared to forest areas. The difference in altitude among the two sites may also play a factor with regards to the difference in fungal population. Siles et al. (2016) reported on the impact of altitude on the microbial community. They concluded that altitude together with season and site specific-effects determine the microbial community structure. During the study, the two sites also had varying moisture content, which has also been reported to affect the composition of soil microbial community due to differences in drought tolerance (Gray et al., 2011). In the present study, it was observed that the genus Aspergillus was dominant in both the studied sites. Perrone et al. (2011) reported that species that produce spore-bearing structures can be easier to discover. Therefore the reason for the dominance of the Aspergillus can be attributed to the better sporulating features of the genus. Further fungal colony with good sporulating features has also been reported to colonize better on the culture plates (Jena et al., 2015). The genus Aspergillus in particular has been reported for its impact on plant growth and induced resistance against phytopathogens (Kaushal et al., 2020).

\section{Conclusions}

The forest regeneration site (FRS) was found to have a greater improved soil quality and also more fungal population as compared to the shifting cultivation site (SCS). We can conclude that the various edaphic factors such as $\mathrm{pH}$, moisture, temperature, $\mathrm{SOC}$ and available nitrogen and altitude have impact on the soil fungal population, thereby effecting soil health in both the site of different land use practises. Thus mitigating soil quality deterioration can be achieved by maintaining the fallow period and implementing a shorter cultivation cycle. A sustainable method of shifting cultivation must be implemented in order to prevent further deterioration of soil quality.

\section{Acknowledgements}

JRF-Fellowship, File no. 16-6 (Dec 2018)/2019(NET/ CSIR) provided by the CSIR-UGC, Government of India, Nationality Eligibility Test (NET) is acknowledge for supporting the work financially. The Head, Department of Botany, Nagaland University is duly acknowlegded for providing necessary laboratory facilities for conducting the experiments.

\section{Conflict of interest}

The authors declares no conflict of interest.

\section{References}

Arevalo, C., Chang, S. X., Bhatti, J. S., \& Sidders, D. (2012). Mineralization potential and temperature sensitivity of soil organic carbon under different land uses in the parkland region of Alberta, Canada. Soil Science Society of American Journal, 76(1), 241-251. https://doi.org/10.2136/sssaj2011.0126 
Bruce, J. P., Frome, M., Haites, E., Janzen, H. H., Lal, R., \& Paustian, K. (1999). Carbon sequestration in soils. Journal of Soil and Water Conservation, 54(1), 382-389.

Campbell, C. A., Zentner, R. P., Janzen, J. J., \& Bowren. K. E. (1990). Crop rotation studies on the Canadian Prairies (Publ. No. 184/E). Canadian Gov. Publ. Centre, Supply \& Services Canada, Hull, QC.

Chang, R. Y., Fu, B. J., Liu, G. H., \& Liu, S. G. (2011). Soil carbon sequestration potential for "Grain for Green" project in Loess Plateau, China. Environmental Management, 48(6), 1158-1172. https://doi.org/10.1007/s00267-011-9682-8

Dadhwal, K. S., Mandal, D., Srimali, S. S., Dhyani, S. K., Mohan, S. C., \& Raizada, A. (2011). Landscape-scale soil quality assessment under different land use systems in north-western hilly region. Indian Journal of Soil Conservation, 39(2), 128-135.

Dar, M. A., Wani, J. A., Raina, S. K., Bhat, M. Y., Malik, M. A., \& Najar, G. R. (2012). Effect of altitude and depth on available nutrients in pear orchard soils of Kashmir. Agropedology, 22(2), 115-118.

Dar, Z. A., Humaira, Q., Ahmad, M. S., Bilal, B., \& Amin, A. (2018). Assessment of physico-chemical parameters of forest soil of Hirpora Wildlife Sanctuary, Kashmir. International Journal of Advance Research in Science and Engineering, 7(4), 46-56.

Deng, L., Wang, K. B., Chen, M. L., Shangguan, Z. P., \& Sweeney, S. (2013). Soil organic carbon storage capacity positively related to forest succession on the Loess Plateau, China. Catena, 110, 1-7. https://doi.org/10.1016/j.catena.2013.06.016

Devi, N. L., \& Choudhury, B. U. (2013). Soil fertility status in relation to fallow cycles and land use practices in shifting cultivated areas of Chandel district Manipur, India. Journal of Agriculture and Veterinary Sciences, 4(4), 1-9.

https://doi.org/10.9790/2380-0440109

Doran, J. W., \& Parkin, T. B. (1994). Defining and assessing soil quality. In J. W. Doran, D. C. Coleman, D. F. Bezdicek, \& B. A. Steward (Eds.), Defining soil quality for a sustainable environment. Soil Science Society of America, Inc. https://doi.org/10.2136/sssaspecpub35.c1

Duguma, B., Gockowski, J., \& Bakala, J. (2001). Smallholder cacao (Theobroma cacao Linn.) cultivation in agroforestry systems of West and Central Africa: Challenges and opportunities. Agroforestry Systems, 51(3), 77-188.

https://doi.org/10.1023/A:1010747224249

Gillman, J. C. (1957). A manual of soil fungi ( $\left.2^{\text {nd }} \mathrm{rev} . \mathrm{ed}.\right)$. Oxford and IBH Publishing Company (Indian reprint) Calcutta, Bombay, New Delhi.

Gray, S. B., Classen, A. T., Kardol, P., Yermakov, Z., \& Michael, M. R. (2011). Multiple climate change factors interact to alter soil microbial community structure in an old-field ecosystem. Soil Science Society of America Journal, 75(6), 2217-2226. https://doi.org/10.2136/sssaj2011.0135

Gupta, R. D., Bhardwaj, K. R., Morwan, B. C., \& Tripathi, B. R. (1986). Occurrences of phosphate dissolving bacteria in soils of North Hymalatas under varying biosequence and climosequence. Journal of Indian Society of Soil Science, 34, 498-504.

Hume, A., Chen, H. Y., Taylor, A. R., Kayahara, G. J., \& Man, R. (2016). Soil C:N:P dynamics during secondary succession following fire in the boreal forest of central Canada. Forest Ecology and Management, 369, 1-9.

https://doi.org/10.1016/j.foreco.2016.03.033

Jena, S. K., Tayung, K., Rath, C. C., \& Parida, D. (2015). Occurrence of culturable soil fungi in a tropical moist deciduous forest Similipal Biosphere Reserve, Odisha, India. Brazilian
Journal of Microbiology, 46(1), 85-96.

https://doi.org/10.1590/S1517-838246120131367

Jenkins, A. (2005). Soil fungi. In Soil biology basics. Information series. NSW Department of Primary Industries. https://www. dpi.nsw.gov.au/_data/assets/pdf_file/0020/41645/Soil_fungi. pdf

Jones, O. R., \& Popham. T. W. (1997). Cropping and tillage practices for dry land grain production in the Southern High Plains. Agronomy Journal, 89(2), 222-232.

https://doi.org/10.2134/agronj1997.00021962008900020012x

Karlen, D. L., Varvel, G. E., Bullock, D. G., \& Cruse, R. H. (1994). Crop rotations for the 21st century. Advances in Agronomy, 53, 1-45. https://doi.org/10.1016/S0065-2113(08)60611-2

Kaushal, M., Swennen, R., \& Mahuku, G. (2020). Unlocking the microbiome communities of banana (Musa spp.) under disease stressed (Fusarium wilt) and non-stressed conditions. Microorganisms, 8(3), 443.

https://doi.org/10.3390/microorganisms8030443

Kumar, P. K. R., Hemanth, G., Niharika, P. S., \& Kolli, S. K. (2015). Isolation and identification of soil mycoflora in agricultural fields at Tekkali Mandal in Srikakulam district. International Journal of Advances in Pharmacy, Biology and Chemistry, 4(2), 484-490. http://www.ijapbc.com/files/23-06-15/30-4241.pdf-

Lalmuansangi, Vanlalliantluanga, A., \& Thachunglura, V. L. (2019). Assessment of seasonal variation in soil characteristics with in the surrounding area of Kolasib solid Waste Dumping Ground. International Journal of Science and Research, 10(1), 1117-1123.

https://www.ijsr.net/archive/v10i1/SR21113203504.pdf

Liu, W., Zhang, Z., \& Wan, S. (2009). Predominant role of water in regulating soil and microbial respiration and their responses to climate change in semiarid grassland. Global Change Biology, 15(1), 184-195.

https://doi.org/10.1111/j.1365-2486.2008.01728.x

Maithani, B. P. (2005). Shifting cultivation in North-East India: Policy, issues and options. Mittal Publications.

Mertz, O. (2002). The relationship between length of fallow and crop yields in shifting cultivation: A rethinking. Agroforestry Systems, 55(2), 149-159.

https://doi.org/10.1023/A:1020507631848

Mertz, O., Padoch, C., Fox, J., Cramb, R. A., Leisz, S. J., Lam, N. I., \& Vien, T. D. (2009). Swidden change in Southeast Asia: Understanding causes and consequences. Human Ecology, 37(3), 259-264. https://doi.org/10.1007/s10745-009-9245-2

Miah, S., Dey, S., \& Sirajul Haque, S. M. (2010). Shifting cultivation effects on soil fungi and bacterial population in Chittagong Hill Tracts, Bangladesh. Journal of Forestry Research, 21(3), 311-318. https://doi.org/10.1007/s11676-010-0076-1

Mizra, A. N., \& Patil, S. S. (2020). Assessment of seasonal variation in physicochemical characteristics of the soil at Gautala reserve forest (M.s.), India. Current World Environment, 15(2), 289-303. https://doi.org/10.12944/CWE.15.2.17

Nagmani, A., Kunwar, I. K., \& Manoharachary, C. (2006). Hand book of soil Fungi. I.K. International Publishing House.

Nielsen, D. C., \& Calderón, F. (2011). Fallow effects on soil. In J. L. Hatfield \& T. J. Sauer (Eds.), Soil management: Building a stable base for agriculture (pp. 287-300). American Society of Agronomy and Soil Science Society of America. https://doi.org/10.2136/2011.soilmanagement.c19

Nielsen, D. C., Vigil, M. F., Anderson, R. L., Bowman, R. A., Benjamin, J. G., \& Halvorson, A. D. (2002). Cropping system influence on planting water content and yield of winter wheat. Agronomy Journal, 94(5), 962-967. https://doi.org/10.2134/agronj2002.0962 
Onwuka, B., \& Mang, B. (2018). Effects of soil temperature on some soil properties and plant growth. Advances in Plants and Agricultural Research, 8(1), 34-37. https://doi.org/10.15406/apar.2018.08.00288

Perrone, G., Stea, G., Epifani, F., Varga, J., Frisvad, J. C., \& Samson, A. R. (2011) Aspergillus niger contains the cryptic phylogenetic species A. awamori. Fungal Biology, 115(11), 11381150. https://doi.org/10.1016/j.funbio.2011.07.008

Shiek, M. A., Kumar, M., \& Bussman, R. W. (2009). Altitudinal variation in soil organic carbon stock in coniferous subtropical and broadleaf temperate forests in Garhwal Himalaya. Carbon Balance and Management, 4, 6. https://doi.org/10.1186/1750-0680-4-6

Siles, J. A., Cajthaml, T., Minerbi, S., \& Margesin, R. (2016). Effect of altitude and season on microbial activity, abundance and community structure in Alpine forest soils. FEMS Microbiology Ecology, 92(3), 1-12. https://doi.org/10.1093/femsec/fiw008

Singh, P. K., \& Jamir, A. (2017). Comparative study of soil fertility status of direct seeded and transplanted rice under Kohima district of Nagaland. Journal of Pharmacognosy and Phytochemistry, 6(6S), 64-68.

Singh, P. K., \& Munth, H. (2013). Fertility status of soil under forest and cultivated land use system of Nagaland. Asian Journal of Soil Science, 8(2), 470-475. http://researchjournal.co.in/ upload/assignments/8_470-475.pdf

Smyth, J. T. (2012). Soil acidity and liming. In P. M. Huang, Y. Li, \& M. E. Sumner (Eds.), Handbook of soil sciences: Resource management and environmental impacts ( $2^{\text {nd }}$ ed.) (pp. 373379). CRS Press.

Tasung, A., \& Ahmed, N. (2017). Effect of different land use system and altitude on soil organic carbon and soil fertility of Siang river basin in Arunachal Pradesh, India. Journal of Crop and Weed, 13(3), 126-134. https://www.cropandweed. com/archives/2017/vol13issue3/13-3-25.pdf

Tiessen, H., Cuevas, E., \& Chacon, P. (1994). The role of soil organic matter in sustaining soil fertility. Nature, 371, 783-785. https://doi.org/10.1038/371783a0
Unger, P. W., Stewart, B. A., Parr, J. F., \& Singh, R. P. (1991). Crop residue management and tillage methods for conserving soil and water in semi-arid regions. Soil \& Tillage Research, 20(2), 219-240. https://doi.org/10.1016/0167-1987(91)90041-U

Van N, M., Mulyoutami, E., Sakuntaladewi, N., \& Agus, F. (2008). Swiddens in transition: Shifted perceptions on shifting cultivators in Indonesia (Occasional Paper no. 9). World Agroforestry Centre.

Waksman, S. A. (1921). Method for counting the number of fungi in the soil. Journal of Bacteriology, 7(3), 339-341. https://doi.org/10.1128/jb.7.3.339-341.1922

Walkley, A., \& Armstrong Black, I. (1934). An examination of the Degtjareff method for determining soil organic matter, and a proposed modification of the chromic acid titration method. Soil Science, 37(1), 29-38. https://doi.org/10.1097/00010694-193401000-00003

Webster, J., \& Weber, R. W. S. (2007). Introduction to fungi ( $3^{\text {rd }}$ ed.). Cambridge University Press. https://doi.org/10.1017/CBO9780511809026

Wubie, M. A. (2013). Impacts of land use system on soil properties and fertility status in the Mizewa watershed of lake Tana basin, North Western Ethiopia. International Journal of Research in Commerce, Economics \& Management, 3(9), $120-124$.

Xu, C., Xiang, W., Gou, M., Chen, L., Lei, P., Fang, X., Deng, X., \& Shuai, O. (2018). Effects of forest restoration on soil carbon, nitrogen, phosphorus, and their stoichiometry in Hunan, Southern China. Sustainability, 10(6), 1874. https://doi.org/10.3390/su10061874

Ziegler, A. D., Bruun, T. B., Guardiola-Claramonte, M., Giambelluca, T. W., Lawrence, D., \& Lam, N. T. (2009). Environmental consequences of the demise in Swidden cultivation in montane mainland Southeast Asia: Hydrology and geomorphology. Human Ecology, 37(3), 361-373. https://doi.org/10.1007/s10745-009-9258-X

Zodinpuii, B., Lalnuntluanga, \& Lalthanzara, H. (2016). Impact of shifting cultivation on soil organic carbon in tropical hilly terrain of Mizoram, India. Science Vision, 16(3), 135-143. http://oaji.net/articles/2017/1315-1494504034.pdf 